\title{
An Examination of the Relationships between Leadership Development Approaches, Networking Ability, and Social Capital Outcomes
}

\author{
Bradley Burbaugh, Ph.D. \\ County Extension Director \\ University of Florida IFAS Extension \\ Eric K. Kaufman. Ph.D. \\ Associate Professor \& Extension Specialist \\ Department of Agricultural, Leadership, and Community Education \\ Virginia Tech
}

\begin{abstract}
Participants in leadership development programs take part in multiple developmental experiences that can influence the composition of their social network and enhance social capital. However, further investment in such practices may be limited because little is known about the relationship between leadership development approaches, networking ability, and social capital. This study explores how common developmental approaches may contribute to social capital, taking into consideration the role networking ability plays in this relationship. This descriptive, correlational study included a sample of graduates $(\mathrm{N}=231)$ from 15 statewide agricultural-based leadership development programs. Our findings reveal that: 1) Networking is an antecedent to social capital, 2) skill building and personal growth approaches to leadership development are significant predictors of networking ability, and 3) networking ability is a significant predictor of social capital.
\end{abstract}

\section{Introduction}

Considerable time and resources have been devoted to understanding the outcomes of leadership development programs (LDPs), but little time and effort have been dedicated to examining the relationships between specific learning activities and approaches that affect the emergence of these outcomes (Day \& Dragoni, 2015; Dinh, et al., 2014; Gardner, Lowe, Moss, Mahoney, \& Cogliser, 2010). This disconnect exists because LDPs are often viewed as "blackboxes" that receive inputs (i.e., learning activities) and produce outcomes (i.e., human and social capital) (Stufflebeam \& Shinkfield, 2007). As a result, there is little consideration given to the mechanisms that facilitate the development of individuals and/or groups. Such is the case for the relationships between common approaches to leadership development and their influence on social capital; and even less is known about the relationship between networking ability and these two constructs (Balkundi \& Kilduff, 2006; Collins \& Holton, 2004; Day, 2000; Van De Valk \& Constas, 2011). The lack of a systematic understanding of interplay between these constructs illuminates the need to untangle the relationships between leadership approaches, social capital, and networking ability. 
Leadership programs aim to enhance the capacity of individuals, groups, and organizations through learning activities which serve as the catalyst for development (Rabin, 2014; Van Velsor, McCauley, \& Ruderman, 2010). Most leadership development programs in existence today use a variety of learning approaches to develop the human and social capital of participants (Allen \& Hartman, 2008a; Conger, 1992). Common learning activities associated with the development of leadership capacity can be grouped into the following four approaches: skill building, conceptual understanding, personal growth, or feedback (Allen \& Hartman, 2008a, 2008b; Conger, 1992). Each of these learning approaches differ in their potential contribution to development, but the efficacy of each has been under researched (Conger, 1992; Day, 2000; Dalakoura, 2010, Dinh et al., 2014).

Enhanced social capital has been identified as a primary aim of leadership development (Day, 2000; McCallum \& O'Connell, 2009; Meehan \& Reinelt, 2012). LDPs serve as a medium for the development of social capital because they provide a context for relationship establishment, which can lead to the development of trust, goodwill, and reciprocity (McCallum \& O'Connell, 2009). These relationships are developed and maintained through networking, which is a useful developmental behavior, because it can expand an individual's social network (Kilpatrick, Field, \& Falk, 2003; Uhl-Bien, 2006; Wolff \& Moser, 2010) and increase social capital capacity (de Janasz \& Forret, 2008; Friar \& Eddleston, 2007). As such, networking is a widely reported outcome of leadership program participation (see Black, Metzler, \& Waldrum, 2006; Carter \& Rudd, 2000; Dhanakumar, Rossing, \& Campbell, 1996; Diem \& Nikola, 2005; Kelsey \& Wall, 2003; Roberts, 2013). There is also growing recognition that network-enhancing LDPs "can improve individuals' effectiveness in leadership roles and processes and the collectives' ability to produce leadership" (Cullen-Lester, Maupin, Carter, 2017, p. 131). It should be noted that networking and social capital both consider benefits derived from social relationships; however, networking focuses on individual behavior to build and maintain relationships, while social capital focuses on the characteristics and outcomes of these relationships.

The current economic environment portends the decline for current and future leadership development programs that cannot provide evidence of how their programs develop the capacity of individuals, groups, and organizations. For this study we sought to explore the relationships between inputs and outcomes to address the "black box" by identifying the links between learning approaches, networking ability, and social capital outcomes.

\section{Literature Review}

Leadership Development Approaches. Conger (1992) categorizes leadership development programs into four primary domains based on the following approaches: conceptual understanding, personal growth, skill building, and feedback. Building on Conger's (1992) work, Allen and Hartman (2008a, 2008b, 2009) identified the sources of learning that best align with each developmental approach. It is likely that most leadership development programs in existence today use multiple sources of learning and approaches to accomplish their objectives and mission "because no single approach is appropriate at all times" (Allan \& Hartman, 2008a, p. 85). The approaches advanced by Conger (1992) and the associated sources of learning 
advanced by Allen and Hartman (2008a, 2008b, 2009) can be used to provide a framework for understanding the learning activities associated with developing leader capacity (Table 1).

Table 1

Leadership development approaches and corresponding learning activities.

\begin{tabular}{|c|c|}
\hline Leadership Approach & Common Learning Activities \\
\hline Conceptual Understanding & $\begin{array}{l}\text { Case studies } \\
\text { Video clips } \\
\text { Lectures } \\
\text { Expert panels } \\
\text { Tours } \\
\text { Storytelling } \\
\text { Observation of leaders } \\
\text { Articles or books } \\
\text { Research leadership } \\
\text { E-learning } \\
\text { Classroom-based training } \\
\text { Self-study } \\
\text { Small group discussion }\end{array}$ \\
\hline Feedback & $\begin{array}{l}360 \text { Feedback } \\
\text { Coaching } \\
\text { Assessments and instruments } \\
\text { Audio or video feedback }\end{array}$ \\
\hline Personal Growth & $\begin{array}{l}\text { Written reflections } \\
\text { Group reflection } \\
\text { Personal vision statements } \\
\text { Service learning } \\
\text { Networking } \\
\text { Team building activities }\end{array}$ \\
\hline Skill Building & $\begin{array}{l}\text { Ropes or team courses } \\
\text { Icebreakers } \\
\text { Simulations } \\
\text { Games } \\
\text { Role playing activities } \\
\text { Personal development plans } \\
\text { Action learning } \\
\text { Group or individual presentations } \\
\text { Group projects }\end{array}$ \\
\hline
\end{tabular}

Note: Adapted from Conger (1992) and Allen \& Hartman (2008a, 2008b, 2009). 
Networking. Networking is characterized as an individual level construct to describe interrelated behaviors that can be frequently and consistently exhibited by individuals (Wolff, Moser, \& Grau, 2008). Networking is a key human capital competency that has been found to be sensitive to interventions like training and development (Collins \& Clark, 2003). In 2004, Russon and Reinelt reviewed evaluations from 55 leadership development programs and concluded, "some of the most powerful and enduring outcomes of leadership programs are the relationships that are formed between participants in the programs" (p. 8). These relationships are developed and maintained through network maintenance behaviors (Kilpatrick, Field, \& Falk, 2003; Uhl-Bien, 2006; Wolff \& Moser, 2010). These relationship maintenance behaviors are "considered an investment in social relationships that one anticipates will eventually pay off" (Wolff, Moser, \& Grau, 2008, p. 104).

In the leadership context, networking is a particularly useful competency, as it provides the means for an individual to increase the number and diversity of relationships in their social network (Kilpatrick, Field, \& Falk, 2003; Uhl-Bien, 2006; Pearce, 2007; Wolff \& Moser, 2010). Networking can enhance social capital capacity by influencing the size, strength, and pattern of relationships as well as resources embedded in an individual's social network (de Janasz, \& Forret, 2008). Consequently, networking ability has been implicated as an antecedent to social capital formation (Kostova \& Roth, 2003; Lin, 2001; Wolff, Moser, \& Grau, 2008). Additionally, networking has been found to be a highly social activity; therefore, networking ability is facilitated by certain traits like extraversion (Wanberg, Kanfer, \& Banas, 2000). In their comprehensive review of networking behavior correlates, Forret and Dougherty (2001) conclude that extraversion was a significant predictor of networking ability and should be included in future research on networking.

Social Capital. Given that networking has been described as an investment in social relationships (Wolff, Moser, Grau, 2008); clearly then, the return on this investment (i.e., social capital) is important. Social capital represents the relational resources attainable by individuals through their networks of social relationships (Coleman, 1988; Putnam, 1995). Putnam (1993) describes social capital as the "features of social organization such as networks, norms, and social trust that facilitate coordination and cooperation for mutual benefit" (p. 35). Social capital develops through stages characterized by contact, assimilation, and mutual identification experiences (Bilhuber Galli \& Müller-Stewens, 2012). Leadership development programs serve as a medium for the development of social capital because they provide a context for relationship establishment, which can lead to the development of trust, goodwill, and reciprocity (McCallum \& O'Connell, 2009). Balkundi and Kilduff (2005) write, "Leadership can be understood as social capital that collects around certain individuals" (p. 943).

Drawing on a comprehensive review of social capital literature, Nahapiet and Ghoshal (1998) concluded that social capital is a multi-dimensional construct. Due to their alignment with the aims of leadership development, and the leadership literature, we explored the following dimensions of social capital for this study: groups and networks, trust and solidarity, and cooperation and political action (See Gutiérrez, Hilborn, \& Defeo, 2011; Mehra, Dixon, Brass, \& Robertson, 2006; Nistler, 2014; Purdue, 2001). The groups and networks dimension reflects network structure and connectivity levels (Burt, 1992; Lee \& Jones, 2008), whereas the trust and solidarity dimension addresses the normative conditions that characterize the relationships and 
guide social exchanges (Tsai \& Ghoshal, 1998). The cooperation and political action dimension reflect social capital outcomes. This dimension is described as the highest level of social capital because it is where structure (i.e., groups and network) and trust meet to facilitate action (Grootaert et al., 2004, p. 5). Thus conceived, social capital can be understood as a multidimensional construct that encompasses elements that intersect structure and action (Lin, 1999). These elements include the structure, content and perception, as well as outcomes associated with relationships within a given network (Nahapiet \& Ghoshal, 1998; Tsai \& Ghoshal, 1998). As such, social capital is indicative of the relationships embedded in a social network, the norms that afford access to such social resources, and the mobilization of such resources in the pursuit of purposive action (Lin, 1999; Putnam, 2000).

\section{Conceptual Model}

The development of social capital has been described as the primary aim of leadership development (Day, 2000) and networking has been described as an antecedent to social capital formation (Kostova \& Roth, 2003); thus, the relationship between leadership development approaches and networking ability plays an important role in this research (Figure 1). As this model illustrates, networking ability may in influence the emergence of social capital outcomes.

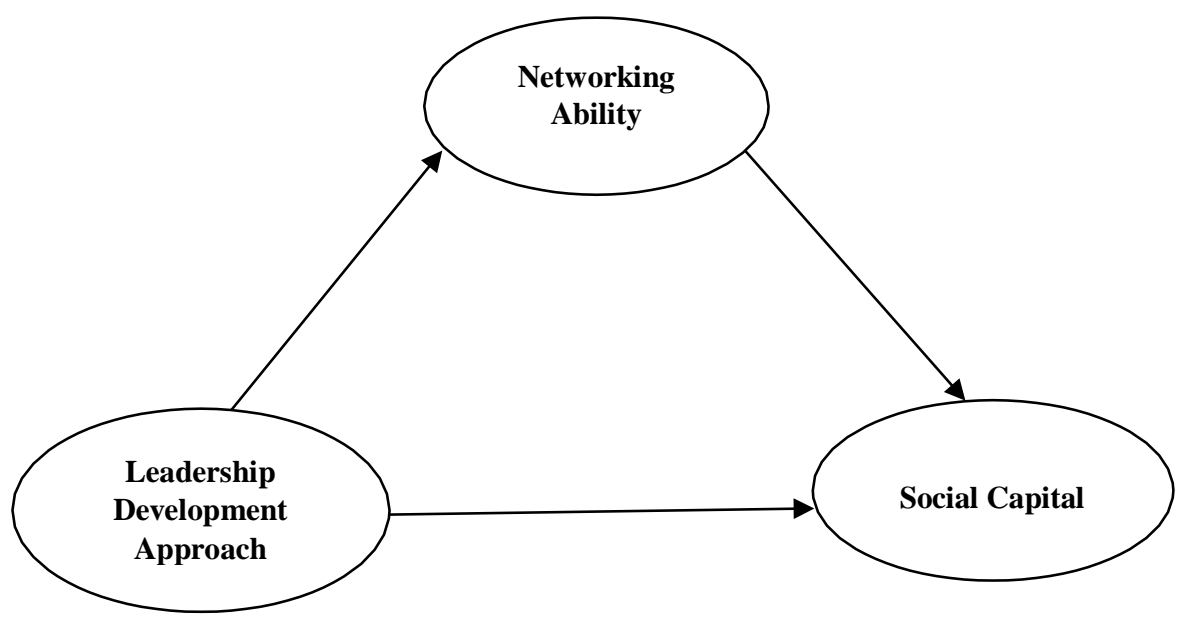

Figure 1. Conceptual model illustrating the theoretical relationships between leadership development, networking ability, and social capital.

\section{Research Purpose and Question}

The purpose of our study was to explore the nexus between leadership development approaches, social capital dimensions, and networking ability. In doing so we address the programmatic assessment and evaluation priority of the Association of Leadership Educator's national research agenda (Andenoro, et al., 2013). The research objectives aimed to:

1. Examine the relationships between leadership development approaches, networking ability, and social capital. 
2. Determine the predictive capacity of leadership development approaches and networking ability on social capital.

By investigating these relationships, this study answers calls to untangle the relationships between these constructs (Van De Valk \& Constas, 2011), contextualizes social capital research (Day, 2000), and provides a better understanding of the approaches that affect the emergence of leadership program outcomes (Dinh, et al., 2014).

\section{Methods}

The target population of this descriptive-correlational study consisted of individuals who graduated (i.e., alumni) from U.S. agricultural leadership programs during the previous five year period. This timeframe was selected to protect against recall bias, and is supported by previous research that found $50 \%$ of critical details from recognized events are irretrievable from memory after five years (Bradburn, Rips, \& Shevell, 1987). A purposive sampling procedure was employed. Individuals were selected to participate based on their leadership program's willingness to make their graduates available to take part in the study. This sampling procedure was deemed appropriate because "purposive sampling has been useful in attitude and opinion surveys" (Ary, Jacobs, \& Sorensen, 2010, p. 156).

Online survey research was conducted in spring 2015 to address the research objectives. Participants completed a 52-question survey designed by the researchers. The questionnaire includes four sections with items used to measure (a) the number, influence, and intensity of learning activities experienced; (b) networking ability and extraversion; (c) social capital dimensions; and (d) background characteristics such as gender race/ethnicity, occupation, and education level. Many of the items and scales were adapted from existing instruments. An established panel of six experts determined content and face validity of the instrument prior to a pilot test. Based on feedback from these experts and results of the pilot study, the following items and scales were used.

The first scale was researcher-developed and used to construct a composite measure for each participant using the following approaches to leadership development: conceptual understanding, feedback, personal growth, and skill building. Due to the fact that the number of activities associated with each approach varied on a range from four (e.g., feedback) to 13 (e.g., conceptual understanding). The number of activities selected by the participant was divided by the number of activities associated with that approach. Thus, the score associated with learning activities for each approach ranged from zero to one. For example, if a participant selected 11 of 13 activities associated with the conceptual understanding approach, they would receive a score of .85 for that approach.

In an effort to equally weight all three items of the composite (i.e., number of activities, influence, and intensity) this procedure of dividing the number of choices by the participant's response was repeated for the influence scale in order to ensure a range from zero to one. The following Likert-type responses were used calculate the influence scale: $0=$ not at all influential, $1=$ slightly influential, $2=$ somewhat influential, $3=$ very influential, and $4=$ extremely influential. For example, if a respondent reported activities associated with an approach were 
"very influential," that respondent would receive a .80 influence score for that approach. Finally, the percent of time spent devoted to each approach, as reported by participants, was used as an intensity score and added to the activity and influence scores for each approach. For example, if a respondent reported spending $63 \%$ of the time devoted to a particular approach, they would receive a score of .63 for intensity. Thus, each item used to compute the composite was weighted equally (range 0-1) and the composite approach scale ranged from zero to three. The composite approach score for each respondent was calculated as shown in Figure 2 below.

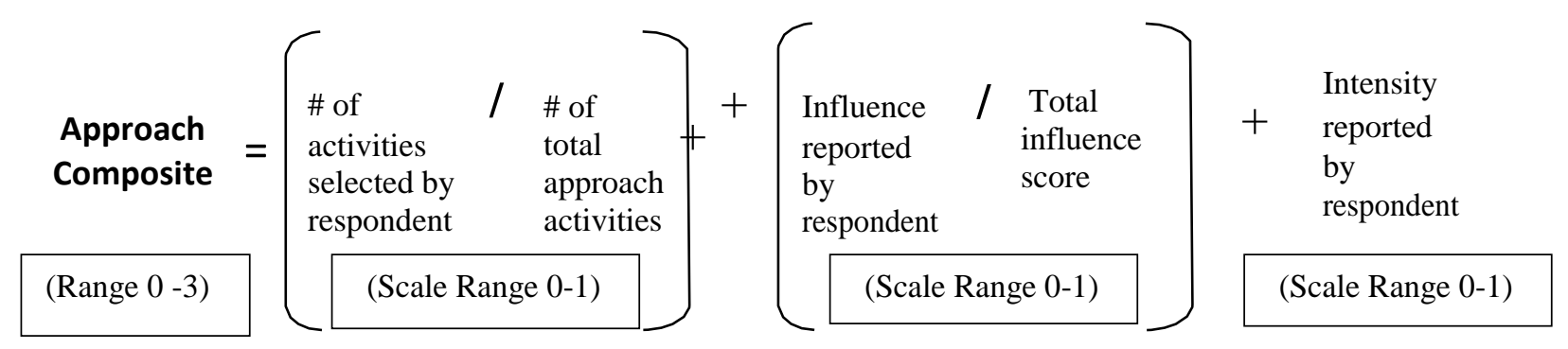

Figure 2. Scales used to develop a composite approach measures for each participant.

The second section of the instrument consisted of two scales to measure the following human capital variables: networking ability and extraversion. Networking ability was measured with a six-item scale developed by Ferris et al. (2005) as part of the political skill inventory. Two sample items from the networking ability scale include: "I spend a lot of time and effort at work networking with others" and "I am good at using my connections and network to make things happen." Response options were based on a seven-point Likert scale ranging from $1=$ "strongly disagree" to 7 = "strongly agree." As a control variable, extraversion was measured with eight questions developed by John, Donahue, and Kentle (1991) and further refined by John, Naumann, and Soto (2008). Two sample questions include: "I am someone who is talkative" and "I am someone who generates a lot of enthusiasm." Response options are on a five-point Likert scale ranging from 1 = "disagree strongly" to 5 = "agree strongly."

The third section of the instrument was used to collect data related to the following dimensions of social capital: groups and networks, trust and solidarity, cooperation and political action. The World Bank (2001) first identified these dimensions, and the instrument to measure these dimensions was developed by Nistler (2014), who used a combination of verbatim and adapted items from two instruments designed by Grootaert, Narayan, Jones, and Woolcock (2004), as well as Onyx and Bullen (2000).

Exploratory factor analysis was used to establish construct validity by identifying and confirming the underlying structure of the items. Principal components analysis with VARIMAX rotation was used to extract factors for each scale. To improve the validity of the measures, scale revisions were made because the EFA results indicated inadequate construct representation, which "occur[s] when a measure does not have the desired location within some conceptual framework" (Reise, Waller, \& Comrey, 2000, p. 288). The a priori criteria for item deletion were heavy loadings on more than one factor and loadings smaller than 0.4. Ford, MacCallum, and Tait (1986) suggest that factor loadings should be higher than 0.4 to be considered 
meaningful. As a result, seven variables were excluded using these guidelines. Additional factor analyses were conducted using the remaining 18 variables loaded onto three factors. The result of the three-factor solution revealed all variables were grouped into the same factor as in the previous factor analysis and the factor loadings and total variance explained increased. Thus, the final three factors were retained. The Bartlett test of sphericity for the three-factor model was significant $\left(\chi^{2}(136)=1391.163, p<.01\right)$, and the Kaiser-Meyer-Olkin measure of sampling adequacy was .803, which is adequate for intercorrelations and factor analysis (Hair et al., 2009). This three-factor solution explained $54 \%$ of the total variance with 18 variables.

Demographic items constitute the fourth and final section of the instrument. The demographics of the sample revealed that the majority of the participants were White-Caucasian $(95.2 \%)$. A slight majority of the sample was male (52.6\%) and the mean age of the participants was $44(\mathrm{SD}=9.98)$. Less than $10 \%$ did not attend college, $4.8 \%$ completed a two-year college degree, $49.8 \%$ had a four-year degree, and $35.8 \%$ had completed a graduate or professional degree.

In addition to establishing face and content validity with a panel of expert reviewers and a pilot study, and construct validity with exploratory factor analysis; we measured the internal consistency of each scale through post-hoc reliability estimates using Cronbach's reliability coefficients; all coefficients for this sample were above $\alpha 0.80$. The researchers implemented methods recommended by Dillman, Smyth, and Christian (2009) to develop the survey and to collect the data. Data collection procedures were guided by the tailored design method(Dillman et al., 2009). All contact with participants, from the initial recruitment letter to the final reminder, was facilitated using electronic mail. The survey remained open for four weeks and the response rate was $29 \%$ with 231 participants. To test for nonresponse bias, early respondents (those responding prior to the third week, $n=150)$ were compared to late respondents $(n=81)$ on the 'total social capital' variable, using an independent samples t-test. There was no significant difference between early and late respondents.

\section{Results}

The goal of objective one was to examine the direction and magnitude of the relationships between leadership developments approaches, networking ability, and social capital dimensions. To accomplish this objective, Pearson Product Moment Correlations were calculated. The magnitude of correlations ranged from negligible to moderate (Table 2) using effect size guidelines from Cohen (1988).

Relationships between leadership approaches and networking ability. We observed significant relationships between each leadership development approach and networking ability. These significant relationships ranged from weak to moderate in magnitude. There were weak positive relationships between conceptual understanding $(r=.168, p<.05)$ and feedback approaches $(r=.239, p<.01)$ with networking ability. There were moderate positive relationships between personal growth $(r=.321, p<.01)$ and skill building approaches $(r=.327, p<.01)$ with networking ability. 
Relationships between networking ability and social capital. We observed significant relationships between networking ability and social capital dimensions, with the exception of trust and solidarity. Networking ability had a weak, positive relationship with the groups and networks dimension $(r=.270, p<.01)$, and a moderate positive relationship with cooperation and political action $(r=.368, p<.01)$.

Table 2

Pearson correlations coefficients, means, and standard deviations of leadership approaches, social capital dimensions, and networking ability ( $\mathrm{N}=231)$.

\begin{tabular}{|c|c|c|c|c|c|c|c|c|c|c|c|c|}
\hline & Variable & M & SD & 1 & 2 & 3 & 4 & 5 & 6 & 7 & 8 & 9 \\
\hline & $\begin{array}{l}\text { Social capital } \\
\text { (all dimensions) }\end{array}$ & 87.35 & 13.88 & & & & & & & & & \\
\hline 2 & $\begin{array}{l}\text { Leadership } \\
\text { approaches } \\
\text { (all approaches) }\end{array}$ & 6.76 & 1.48 & .120 & & & & & & & & \\
\hline 3 & $\begin{array}{l}\text { Conceptual } \\
\text { understanding }\end{array}$ & 1.90 & .40 & .062 & $.722^{* *}$ & & & & & & & \\
\hline 4 & Feedback & 1.38 & .60 & .101 & $.854^{* *}$ & $.515^{* *}$ & & & & & & \\
\hline 5 & Personal Growth & 1.79 & .38 & .106 & $.792^{* *}$ & $.436^{* *}$ & $.526^{* *}$ & & & & & \\
\hline 6 & Skill Building & 1.67 & .47 & .113 & $.834^{* *}$ & $.438^{* *}$ & $.576^{* *}$ & $.666^{* *}$ & & & & \\
\hline 7 & Groups and Networks & 12.84 & 7.60 & $.810^{* *}$ & .112 & .097 & .109 & .118 & .075 & & & \\
\hline 8 & Trust and Solidarity & 61.74 & 6.20 & $.600^{* *}$ & .031 & .003 & .027 & -.019 & .080 & $.174^{* *}$ & & \\
\hline & $\begin{array}{l}\text { Cooperation and } \\
\text { Political Action }\end{array}$ & 12.76 & 5.56 & $.714^{* *}$ & .110 & .117 & .127 & .124 & .089 & $.454^{* *}$ & $.144^{*}$ & \\
\hline & Networking Ability & 5.46 & .90 & $.347^{* *}$ & $.322^{* *}$ & $.168^{*}$ & $.239^{* *}$ & $.321^{* *}$ & $.327^{* *}$ & $.270^{* *}$ & .113 & $.368^{* *}$ \\
\hline
\end{tabular}

Note: $* p<.05, * * p<.01$.

The dependent variables of this study were social capital dimensions; and while these dimensions were not significantly related to the leadership development approaches, the vast majority of relationships were positive with the exception of trust and solidarity dimension and the personal growth approach $(r=-.019, n s)$. Based on these results, a test of the meditational role of networking ability between leadership development approaches and social capital is not appropriate (Baron \& Kenny, 1986). 


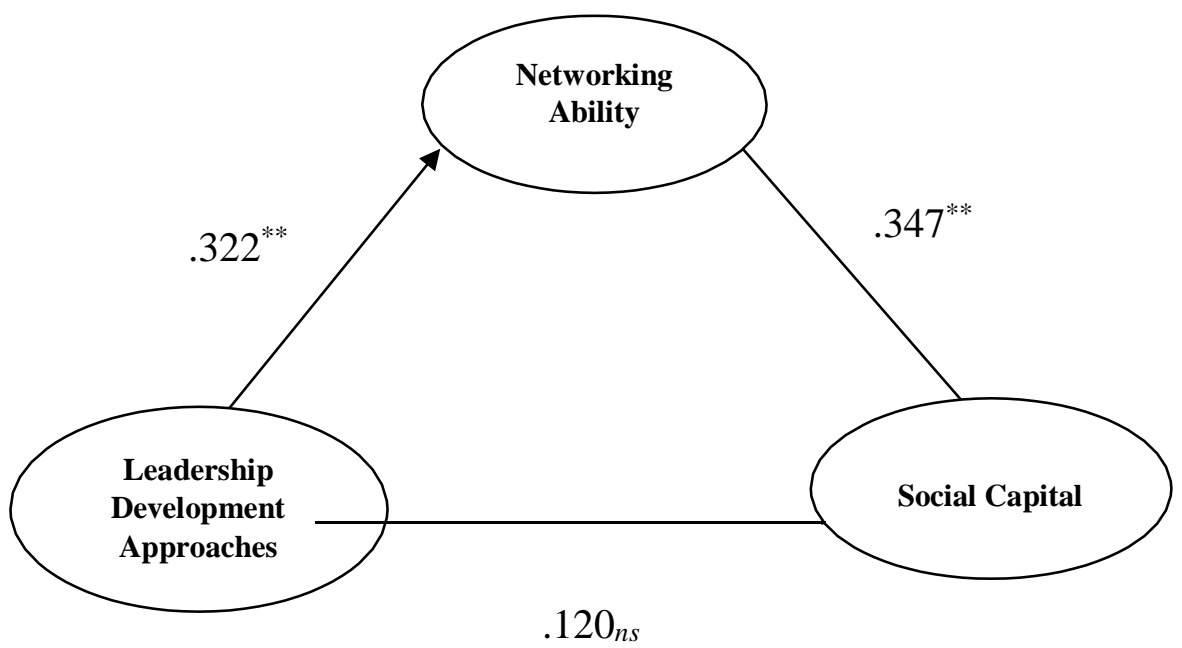

Figure 3. Conceptual model with correlations between leadership development approaches, networking ability, and social capital. Note 1: Although the arrows suggest causal paths, the statistics reported are correlation coefficients $(r)$. Note $2: * * p<.01, n s=$ non-significant.

The goal of objective two was to determine the predictive capacity of leadership development approaches and networking ability on social capital. To accomplish this objective multiple regression analysis and the resulting unstandardized regression coefficients were used to identify predictive capacity.

Leadership Development Approaches Predicting Networking Ability. Individual models for each leadership development approach as a predictor of networking ability were significant when controlling for extraversion (Table 3). According to the analysis, variance in networking ability explained by each leadership development approach ranged for $28 \%$ to $30 \%$.

Table 3

Predicted impact of leadership development approaches on networking ability

\begin{tabular}{lccc}
\hline & $b$ & $\mathrm{R}^{2}$ & $\mathrm{p}$ \\
\hline Constant & & & $.000^{* *}$ \\
Conceptual Understanding & .341 & .28 & $.008^{* *}$ \\
Feedback & .289 & .29 & $.001^{* *}$ \\
Personal Growth & .552 & .30 & $.000^{* *}$ \\
Skill Building & .234 & .30 & $.000^{* *}$ \\
\hline
\end{tabular}

Note 1: $b$ Unstandardized coefficients. Note $2: * p<.05, * * p<.01$.

The next step in the investigation was a full model with all approaches as predictors of networking ability, while controlling for extraversion. This revealed a significant model $(F(1$, $229)=21.371, p<.01)$ that accounts for $32 \%$ of the variance in networking ability $\left(R^{2}=0.323\right)$. However, the only significant predictor in the model was extraversion $(\beta=.456, p<.01)$, and the leadership development approaches became non-significant predictors of networking ability. 
Based on the results of the previous individual models, we further explored the influence of personal growth and skill building approaches on networking ability.

First, model one with personal growth and skill building as predictors on networking without controlling for extraversion was fitted to the data (Table 4). This model was significant $(F(1,229)=16.36, p<.01)$, accounting for $13 \%$ of the variance in networking ability $\left(R^{2}=\right.$ $0.126)$, with both personal growth $(\beta=.185, p<.05)$ and skill building as significant predictors $(\beta=.204, p<.05)$. A second model that controlled for extraversion was fitted to the data and was also found to be significant $(F(1,229)=35.45, p<.01)$, accounting for $32 \%$ of variance in networking ability $\left(R^{2}=0.320\right)$ with extraversion as the only significant predictor of networking ability. However, based on the $\mathrm{R}^{2}$ change from model one to model two $\left(\Delta R^{2}=.126\right)$ it can be concluded that personal growth and/or skill building approaches have a moderate, positive effect (Cohen, 1998) on networking ability.

Table 4

Summary of regression models with personal growth and skill building as predictors of networking ability $(\mathrm{N}=230)$.

\begin{tabular}{|c|c|c|c|c|c|c|c|c|}
\hline \multirow[b]{2}{*}{ Variable } & \multicolumn{5}{|c|}{ Model 1} & \multicolumn{3}{|c|}{ Model 2} \\
\hline & $B^{\mathrm{a}}$ & $\beta^{b}$ & $t$ & Sig. & $B^{\mathrm{a}}$ & $\beta^{b}$ & $t$ & Sig. \\
\hline $\begin{array}{l}\text { Constant } \\
\text { (NA) }\end{array}$ & & & 14.75 & .000 & & & 8.26 & .000 \\
\hline $\begin{array}{l}\text { Personal } \\
\text { Growth }\end{array}$ & $.439^{*}$ & $.185^{*}$ & 2.21 & .027 & .331 & .139 & 1.88 & .061 \\
\hline $\begin{array}{l}\text { Skill } \\
\text { Building }\end{array}$ & $.386^{*}$ & $.204^{*}$ & 2.45 & .015 & .270 & .143 & 1.93 & .055 \\
\hline Extraversion & & & & & $.542^{* *}$ & $.451^{* *}$ & 8.03 & .000 \\
\hline$R^{2}$ & & & .13 & & & & .32 & \\
\hline$\Delta R^{2}$ & & & & & & & .19 & \\
\hline Adjusted $R^{2}$ & & & .12 & & & & .31 & \\
\hline$F$ Statistic & & & $16.36^{* *}$ & .000 & & & $35.45^{* *}$ & .000 \\
\hline
\end{tabular}

Note 1: ${ }^{\mathrm{a}}$ Unstandardized coefficients, ${ }^{\mathrm{b}}$ Standardized coefficients. Note $2: *^{*} p<.01$

Networking Ability Predicting Social Capital. When controlling for extraversion, individual models for networking ability as a predictor of social capital were significant, with the exception of trust and solidarity (Table 5). According to the analysis, variance in social capital dimensions explained by networking ability ranged from negligible to $15 \%$. A full model reveals that networking ability is a significant predictor of total social capital, when controlling for extraversion. Thus, a significant model was found, $\mathrm{F}(1,229)=16.16, p<.01)$, revealing that networking ability accounts for $13 \%$ of the variance in total social capital $\left(R^{2}=0.125\right)$. 
Table 5

Predicted impact of networking ability on social capital dimensions.

\begin{tabular}{lllc}
\hline & $b$ & $\mathrm{R}^{2}$ & $\mathrm{p}$ \\
\hline Constant & & & $.000^{* *}$ \\
Groups and Networks & 1.85 & .08 & $.004^{*}$ \\
Trust and Solidarity & 1.03 & .017 & .051 \\
Political Action & 1.88 & .15 & $.000^{* *}$ \\
\hline
\end{tabular}

Note 1: $b$ Unstandardized coefficients. Note $2: * p<.05, * * p<.01$.

\section{Conclusions \& Recommendations for Practice}

We found links between the inputs (i.e., learning activities) and outputs (i.e., networking ability and social capital outcomes) in this sample of participants from 15 different LDPs; therefore, this study has both theoretical and practical implications for leadership education. Through this exploratory study, we are able to provide a picture of the leadership-networkingsocial capital relationship which provides a firmer basis for planning and implementing learning activities that specifically target networking ability and social capital development in future programs.

The goal of the first objective was to untangle the relationships between the study constructs. We did not find a significant relationship between leadership development and social capital outcomes. However, we did find significant relationships between all of the leadership development approaches and networking ability. These results indicate that a variety of approaches influence the networking ability of program participants.

What is more, personal growth and skill building approaches were the strongest predictors of networking ability. As such, practitioners should spend less time on individualbased learning approaches, like conceptual understanding and feedback, and devote more time to collaborative, group learning activities that characterize the personal growth and skill building approaches. In this study, these were the best approaches, because they allow individuals to network and facilitate relationship building. Some examples of these activities are seminar planning, group reflection, service learning, team building, group projects or presentations, roleplaying, and ropes or team courses. These activities, which provide an opportunity for mutual identification experiences, allow participants to develop skills that helped them relate to others, build commitments, and develop extended social networks (Day, 2000). This finding is further supported by Bilhuber Galli \& Müller-Stewens (2012) who conclude that social capital develops through stages characterized by contact, assimilation, and mutual identification experiences. As such, practitioners should leverage the relational aspects of existing leadership development efforts by redesigning individual-based activities to provide maximum opportunities for social interaction and teamwork (Rabin, 2014). This recommendation is supported by Day (2000), who noted that action learning (i.e., having participants work in teams on real-life problems) is an effective way in which LDPs can help participants build social capital through networking.

The goal of the second objective was to determine the predictive capacity of networking ability on social capital. We did find significant relationships between networking ability and 
social capital outcomes. In this sample of program participants, networking ability was an antecedent to social capital. These findings are supported by the work of Kostova and Roth (2003) who postulated that networking is an antecedent of social capital formation. Furthermore, our findings illuminate the symbiotic relationship between networking and social capital, whereby gains to one will allow for gains to the other. This finding is supported by Nahapiet and Ghoshal (1998), who found human capital skills like communication and networking can enhance relationships, resulting in increased social capital. This conclusion is also supported by Day (2000), who described the relationship between the human and social capital development approaches as symbiotic.

Networking is a particularly useful human capital skill because it influences social capital formation, and, as found in this study, can predict the highest levels of social capital (i.e., cooperation and political action). Pearce (2007) noted that networking ability is a particularly useful developmental area on which to concentrate in future leadership development efforts. Given that networking ability is sensitive to professional learning, greater emphasis should be placed on these approaches in future leadership development programs. For these reasons, a network perspective and networking behavior should be explicitly included in the curricula of leadership development programs, because "Leaders who are skilled networkers have access to people, information, and resources to help solve problems and create opportunities" (Pearce, 2007, p. 6). This approach can help participants develop a better appreciation for "the networks they are already part of and a sense of how, as an emerging network, they might tap into, connects, align, and mobilize across their networks to amplify their impact" (Meehan \& Reinelt, 2012, p. 7). Examples of networking strategies in the leadership development context are asking for feedback, becoming an information hub, making allies, working with others, volunteering for positions and assignments, and learning from others (Grayson \& Baldwin, 2007). This networkenhancing approach has been found to improve the leadership capacity of individuals and collectives (Cullen-Lester, Maupin, Carter, 2017).

The implications from this study are salient because they provide a glimpse inside the black box and present preliminary evidence of the connections between inputs and outputs in leadership development programs. In doing so, this study answers calls to untangle the relationships between leadership development, networking ability, and social capital (Collins \& Holton, 2004; Day, 2000; Van De Valk \& Constas, 2011).

\section{Study Limitations \& Future Research}

Even though the findings of our study are interesting from a practical and theoretical perspective, and have implications for both practice and future research, a few limitations must be acknowledged. First, purposive sampling procedures limits the generalizability. Conclusions and recommendations should only be drawn within the context of this study. Second, any selfreport measures of leadership, networking, and social capital could be viewed as potentially biased. Socially desirable responding may limit participants' ability to accurately represent their behavior. We did take this potential bias into account and used guidelines for online surveys from Joinson (1999), and carefully worded questionnaire items to make the survey less susceptible to social desirability bias (Tourangeau \& Yan, 2007). 
To build on this exploratory study future research should be conducted to assess the social capital of program participants before and after program participation. This research could be conducted using social network analysis and network measures of social capital outlined by Borgatti, Jones, and Everett (1998). The pre-program snapshot of an individual's network could be compared with the post-program snapshot to determine if participation influenced structural social capital. It could also assist in examining the influence of leadership development program participation on network formation, expansion, and density (Nahapiet \& Ghoshal, 1998). Another approach to this research would be a study that utilizes the measures from this study as a pre- and post-program measure of social capital. In this study, the measures provided a snapshot of the respondent's level of social capital. As such, it does not allow the researcher to quantitatively conclude that the level of social capital on the dimensions under study changed as a result of the program. Despite the limitations of this study, the results answer calls to better understand the approaches that affect the emergence of leadership program outcomes (Dinh et al., 2014).

\section{References}

Allen, S. J., \& Hartman, N. S. (2008a). Leadership development: An exploration of sources of learning. S.A.M. Advanced Management Journal, 73(1), 10-19.

Allen, S. J., \& Hartman, N. S. (2008b). Leader development: An exploration of sources of learning. Organization Development Journal, 26(2), 75-87.

Allen, S. J., \& Hartman, N. S. (2009). Sources of learning in student leadership development programming. Journal of Leadership Studies, 3(3), 6-16. doi:10.1002/jls.20119

Andenoro, A. C., Allen, S. J., Haber-Curran, P., Jenkins, D. M., Sowcik, M., Dugan, J. P., \& Osteen, L. (2013). National leadership education research agenda 2013-2018: Providing strategic direction for the field of leadership education. Retrieved from Association of Leadership Educators.

Ary, D., Jacobs, L.C., \& Sorensen, C. (2010). Introduction to research in education ( $8^{\text {th }}$ ed.). Belmont, CA: Wadsworth

Balkundi, P., \& Kilduff, M. (2005). The ties that lead: A social network approach to leadership. The Leadership Quarterly, 16(6), 941-961. doi:10.1016/j.leaqua.2005.09.004

Baron, R. M., \& Kenny, D. A. (1986). The moderator-mediator variable distinction in social psychological research: Conceptual, strategic, and statistical considerations. Journal of Personality and Social Psychology, 51(6), 1173.

Bilhuber Galli, E., \& Müller-Stewens, G. (2012). How to build social capital with leadership development: Lessons from an explorative case study of a multibusiness firm. The Leadership Quarterly, 23(1), 176-201. doi:10.1016/j.leaqua.2011.11.014 
Black, A. M., Metzler, D. P., \& Waldrum, J. (2006). That program really helped me: Using focus group research to measure the outcomes of two statewide leadership programs. Journal of Leadership Education, 5(3), 53-65. doi: 10.12806/v5/i3/rf2

Bradburn, N. M., Rips, L. J., \& Shevell, S. K. (1987). Answering autobiographical questions: The impact of memory and inference on surveys. Science, 236(4798), 157-161.

Borgatti, S. P., Jones, C., \& Everett, M. G. (1998). Network measures of social capital. Connections, 21(2), 27-36.

Burt, R. S. (1992). Structural holes: The social structure of competition. Cambridge, MA: Harvard Press.

Carter, H., \& Rudd, R. D. (2000). Evaluation of the Florida leadership program for agriculture and natural resources. Journal of Southern Agricultural Education Research, 50(1), 199205.

Cohen, J. (1998). Statistical power analysis for the behavioral sciences $\left(2^{\text {nd }}\right.$ ed.). Hillsdale, NJ: Lawrence Erlbaum Associates.

Coleman, J. S. (1988). Social capital in the creation of human capital. American Journal of Sociology, 94, S95-S120.

Collins, C. J., \& Clark, K. D. (2003). Strategic human resource practices, top management team social networks, and firm performance: The role of human resource practices in creating organizational competitive advantage. Academy of Management Journal, 46(6), 740751.

Collins, D. B., \& Holton, E. F. (2004). The effectiveness of managerial leadership development programs: A meta analysis of studies from 1982 to 2001. Human Resource Development Quarterly, 15(2), 217-248. doi:10.1002/hrdq.1099

Conger, J. A. (1992). Learning to lead: The art of transforming managers into leaders. San Francisco, CA: Jossey-Bass.

Cullen-Lester, K. L., Maupin, C. K., \& Carter, D. R. (2017). Incorporating social networks into leadership development: A conceptual model and evaluation of research and practice. The Leadership Quarterly, 28(1), 130-152.

Dalakoura, A. (2010). Differentiating leader and leadership development: A collective framework for leadership development. Journal of Management Development, 29(5), 432-441. doi:10.1108/02621711011039204

Day, D. V. (2000). Leadership development: A review in context. The Leadership Quarterly, 11(4), 581-613. doi:10.1016/S1048-9843(00)00061-8 
Day, D. V., \& Dragoni, L. (2015). Leadership development: An outcome-oriented review based on time and levels of analyses. Annual Review of Organizational Psychology and Organizational Behavior, 2(1), 133-156.

de Janasz, S. C., \& Forret, M. L. (2008). Learning the art of networking: A critical skill for enhancing social capital and career success. Journal of Management Education, 32(5), 629-650. doi:10.1177/1052562907307637

Diem, K. G., \& Nikola, M. P. (2005). Evaluating the impact of a community agricultural leadership development program. Journal of Extension [On-line], 43(6) Article 6RIB5. Available at: http://www.joe.org/joe/2005december/rb5.php

Dillman, D. A., Smyth, J. D., \& Christian, L. M. (2009). Internet, mail, and mixed-mode surveys: The tailored design method ( $3^{\text {rd }}$ ed.). Hoboken, NJ: John Wiley \& Sons.

Dinh, J. E., Lord, R. G., Gardner, W. L., Meuser, J. D., Liden, R. C., \& Hu, J. (2014). Leadership theory and research in the new millennium: Current theoretical trends and changing perspectives. The Leadership Quarterly, 25(1), 36-62. doi:10.1016/j.leaqua.2013.11.005

Dhanakumar, V. G., Rossing, B., \& Campbell, G. R. (1996). An evaluation of the Wisconsin rural leaders perspective program. Journal of Extension, [On-line], 34(3) Article 3RIB3. Available at: http://www.joe.org/joe/1996june/rb3.php

Ferris, G. R., Davidson, S. L., \& Perrewe, P. L. (2005). Political skill at work. Boston, MA: Davies-Black.

Ford, J. K., MacCallum, R. C., \& Tait, M. (1986). The application of exploratory factor analysis in applied psychology: A critical review and analysis. Personnel Psychology, 39(2), 291314.

Forret, M. L., \& Dougherty, T. W. (2001). Correlates of networking behavior for managerial and professional employees. Group \& Organization Management, 26(3), 283-311.

Friar, J. H., \& Eddleston, K. A. (2007). Making connections for success: A networking exercise. Journal of Management Education, 31(1), 104-127.

Gardner, W. L., Lowe, K. B., Moss, T. W., Mahoney, K. T., \& Cogliser, C. C. (2010). Scholarly leadership of the study of leadership: A review of The Leadership Quarterly's second decade, 2000-2009. The Leadership Quarterly, 21(6), 922-958. doi:10.1016/j.leaqua.2010.10.003

Grootaert, C., Narayan, D., Nyhan Jones, V., \& Woolcock, M. (2004). Measuring social capital an integrated questionnaire. Washington, DC: World Bank.

Gutiérrez, N. L., Hilborn, R., \& Defeo, O. (2011). Leadership, social capital and incentives promote successful fisheries. Nature, 470(7334), 386-389. 
Hair, J. F., Black, W. C., Babin, B. J., \& Anderson, R. E. (2009). Multivariate data analysis (7th ed.). Upper Saddle River, NJ: Pearson Education, Inc.

John, O. P., Donahue, E. M., \& Kentle, R. L. (1991). The Big Five Inventory-versions 4a and 54. Berkeley, CA: University of California, Berkeley, Institute of Personality and Social Research

John, O. P., Naumann, L. P., \& Soto, C. J. (2008). Paradigm shift to the integrative Big-Five trait taxonomy: History, measurement, and conceptual issues. In O. P. John, R. W. Robins, \& L. A. Pervin (Eds.), Handbook of personality: Theory and research (pp. 114-158). New York, NY: Guilford Press.

Joinson, A. (1999). Social desirability, anonymity, and Internet-based questionnaires. Behavior Research Methods, Instruments, \& Computers, 31(3), 433-438.

Kelsey, K. D., \& Wall, L. J. (2003). Do agricultural leadership programs produce community leaders? A case study of the impact of an agricultural leadership program on participants' community involvement. Journal of Agricultural Education, 44(4), 35-46. doi: 10.5032/jae.2003.040305

Kilpatrick, S., Field, J., \& Falk, I. (2003). Social capital: An analytical tool for exploring lifelong learning and community development. British Educational Research Journal, 29(3), 417-433.

Kostova, T., \& Roth, K. (2003). Social capital in multinational corporations and a micro-macro model of its formation. Academy of Management Review, 28(2), 297-317.

Lee, R., \& Jones, O. (2008). Networks, communication and learning during business start-up: The creation of cognitive social capital. International Small Business Journal, 26(5), 559-594. doi:10.1177/0266242608094030

Lin, N. (1999). Building a network theory of social capital. Connections, 22(1), 28-51.

Lin, N. (2001). Social capital: A theory of social structure and action. Cambridge, UK: Cambridge University Press.

McCallum, S., \& O’Connell, D. (2009). Social capital and leadership development: Building stronger leadership through enhanced relational skills. Leadership \& Organization Development Journal, 30(2), 152-166. doi: 10.1108/01437730910935756

Meehan, D., \& Reinelt, C. (2012). Leadership \& networks-new ways of developing leadership in a highly connected world. Leadership for a new era series. San Francisco, CA: Leadership Learning Community. 
Mehra, A., Dixon, A. L., Brass, D. J., \& Robertson, B. (2006). The social network ties of group leaders: Implications for group performance and leader reputation. Organization Science, 17(1), 64-79.

Nahapiet, J., \& Ghoshal, S. (1998). Social capital, intellectual capital, and the organizational advantage. The Academy of Management Review, 23(2), 242-266. doi:10.2307/259373

Nistler, D.L. (2014). The impact of 4-H civic engagement education on communities: A measure of social capital in 4-H alumni (Doctoral dissertation). Retrieved from http://gradworks.umi.com. (3647851)

Onyx, J., \& Bullen, P. (2000). Measuring social capital in five communities. The Journal of Applied Behavioral Science, 36(1), 23-42.

Pearce, C. L. (2007). The future of leadership development: The importance of identity, multilevel approaches, self-leadership, physical fitness, shared leadership, networking, creativity, emotions, spirituality and on-boarding processes. Human Resource Management Review, 17(4), 355-359. doi:10.1016/j.hrmr.2007.08.006

Purdue, D. (2001). Neighborhood governance: Leadership, trust and social capital. Urban Studies, 38(12), 2211-2224.

Putnam, R. D. (1993). Making democracy work: Civic traditions in modern Italy. Princeton, NJ: Princeton University Press.

Putnam, R. D. (1995). Tuning in, tuning out: The strange disappearance of social capital in America. Political Science and Politics, 28(4), 664-683. doi:10.2307/420517

Putnam, R. D. (2000). Bowling alone: The collapse and revival of American community. New York, NY: Simon \& Schuster.

Rabin, R. (2014). Blending learning for leadership: The CCL approach. Greensboro, NC: Center for Creative Leadership.

Reise, S. P., Waller, N. G., \& Comrey, A. L. (2000). Factor analysis and scale revision. Psychological Assessment, 12(3), 287-297. doi: 10.1037//1040-3590.12.3.287

Roberts, C. (2013). Building social capital through leadership development. Journal of Leadership Education, 12(1), 54-73.

Russon, C., \& Reinelt, C. (2004). The results of an evaluation scan of 55 leadership development programs. Journal of Leadership \& Organizational Studies, 10(3), 104-107.

Stufflebeam, D. L., \& Shinkfield, A. J. (2007). Evaluation theory, models, and applications. San Francisco: CA: Jossey-Bass. 
Tourangeau, R., \& Yan, T. (2007). Sensitive questions in surveys. Psychological bulletin, 133(5), 859 .

Tsai, W., \& Ghoshal, S. (1998). Social capital and value creation: The role of intrafirm networks. The Academy of Management Journal, 41(4), 464-476. doi:10.2307/257085

Uhl-Bien, M. (2006). Relational leadership theory: Exploring the social processes of leadership and organizing. The Leadership Quarterly, 17(6), 654-676.

doi: 10.1016/j.leaqua.2006.10.007

Van De Valk, L. J., \& Constas, M. A. (2011). A methodological review of research on leadership development and social capital: Is there a cause and effect relationship? Adult Education Quarterly, 61(1), 73-90.

Van Velsor, E., McCauley, C.D., \& Ruderman, M.N. (2010). The center for creative leadership handbook of leadership development. San Francisco, CA: John Wiley \& Sons.

Wanberg, C. R., Kanfer, R., \& Banas, J. T. (2000). Predictors and outcomes of networking intensity among unemployed job seekers. Journal of Applied Psychology, 85(4), 491503. doi:10.1037/0021-9010.85.4.491

Wolff, H.-G., \& Moser, K. (2010). Do specific types of networking predict specific mobility outcomes? A two-year prospective study. Journal of Vocational Behavior, 77(2), 238245. doi:10.1016/j.jvb.2010.03.001

Wolff, H. G., Moser, K., \& Grau, A. (2008). Networking: Theoretical foundations and construct validity. In J. Deller (Ed.), Readings in applied organizational behavior from the Lüneburg Symposium (pp. 101-118). Mehring, Germany: Rainer Hampp.

World Bank. (2001). World Development Report 2000/2001: Attacking Poverty. New York: Oxford University Press. 


\section{Author Biographies}

Dr. Bradley Burbaugh (brad784@ufl.edu) is county-based faculty member and director of the University of Florida IFAS Extension in Clay County, Florida. His research interests include adult leadership development, social capital, networking ability, and evaluation processes.

Dr. Eric K. Kaufman (ekk@vt.edu) is an associate professor in the Department of Agricultural, Leadership, and Community Education at Virginia Tech, where he teaches leadership courses for students in all disciplines at the graduate and undergraduate levels. He coordinates Virginia Tech's graduate certificate program in Collaborative Community Leadership and assists in coordination of the undergraduate Leadership and Social Change minor. Eric's research interests include collegiate leadership education and leadership development with adults in community and volunteer settings. 